\title{
Marketing Mix for Tutoring Agencies During the Pandemic in Indonesia
}

\author{
Fajar Budiyanto*, Eka Indah Nurlaili, Dwi Sembe Sigita \\ Faculty of Economics \\ Mayjen Sungkono University \\ Mojokerto, Indonesia \\ *fajarquantum@gmail.com
}

\begin{abstract}
The temporary closure of formal educational institutions in an effort to contain the spread of the Covid-19 epidemic around the world has an impact on the education sector, not except in Indonesia. The non-formal education sector, such as the Tutoring Business Agencies, also experienced a very significant impact, where the tutoring agencies had difficulty in implementing the marketing mix. So that further studies are needed so that the tutoring business agencies will survive in a pandemic condition. To obtain data, it was done through literature studies from secondary and qualitative data. The habits of students who tend to prefer face-to-face activities make online tutoring activities less responsive and still choose face-toface learning as one way to keep up with the school curriculum. The solution so that tutoring agencies can survive is to improve product and process factors. The products include limiting the number of students in the class and the variety of online and offline learning. The process is by spraying disinfectant at each class change and providing distance between students. This needs to be done so that parents who provide the needed funds will feel safe when their children study at the desired tutoring agencies.
\end{abstract} 19

Keywords—tutoring agencies, marketing mix, pandemic Covid-

\section{INTRODUCTION}

Tutoring business agencies or other name tuition center, have been a part of the world of education in Indonesia since the 1970s, until 2017 there were nearly 2000 officially registered tutoring agencies. Initially, the tutoring provided preparatory services for Senior High School students to participate in the selection to enter state universities. Recently, the business of intensive college entrance test services has expanded even further, targeting Elementary and Junior High School students in various cities in the country. Students who take part in the tutoring show more self-confidence than those who don't, so that there are still a lot of enthusiasts in the tutoring [1].

Since 2015, the National Examination no longer determines student graduation. However, the National Examination is still implemented as a means of mapping and measuring the quality of education. This does not have a significant impact, where students who choose to study with the help of tutoring agencies are still booming. In 2021, the Ministry of Education and Culture plans to remove the National Examination. Several large tutoring agencies business tactic is to adapt the material curriculum established by the government. In 2017 there was a big change in the form of tutoring agencies, from the conventional form of face-to-face to online which began to spread. Online tutoring is a trend that cannot be hindered as a result of technological advances, however, with a higher price than online tutoring, conventional tutoring is still an option.

A big problem at the end of 2019, the outbreak of a type of corona virus changed the education system almost all over the world, including Indonesia. The learning method, which has been in the form of face to face, has turned online using all available media. This is in accordance with the stipulation of the Minister of Education and Culture of the Republic of Indonesia regarding Circular Number 4 of 2020 concerning Implementation of Education Policies in the Emergency of the Spread of Covid-19. Tutoring agencies that already have big brands tend to be better able to survive because of advertisements both from friends and the media, although there are also many small tutoring agencies that are still able to survive in this pandemic era. For this reason, it is necessary to carry out further studies on tips so that conventional tutoring agencies can still survive in the midst of a pandemic condition due to this corona virus.

\section{METHODS}

The method used was a literature study with secondary data collection and qualitative data. In data collection, the authors collected data about covid-19 and its impact on the development of tutoring agencies, especially the top 5 provinces with conventional tutors. In qualitative writing, data presentation can be done in the form of short descriptions, charts, relationships between categories and the like, but the most frequently used is narrative text.

\section{RESULTS}

Non-formal education is defined as all the implementation of education that is carried outside official educational institutions or does not originate from the school environment 
and their existence is protected by law. The number of covid19 chases andtutoring agencies in Indonesia can be seen in Table 1.

TABLE I. THE NUMBER OF COVID-19 CHASES AND TUTORING AGENCIES IN INDONESIA [2,3]

\begin{tabular}{|l|c|c|c|}
\hline \multicolumn{1}{|c|}{ Province } & Chases & Percent & $\begin{array}{c}\text { Number of } \\
\text { Tutoring Agencies }\end{array}$ \\
\hline DKI Jakarta & 65,687 & 25,5 & 115 \\
\hline East Java & 41,755 & 16,2 & 344 \\
\hline Central Java & 20,239 & 7,9 & 166 \\
\hline West Java & 18,593 & 7,2 & 340 \\
\hline North Sumatera & 9,653 & 3,8 & 139 \\
\hline
\end{tabular}

The number of educational businesses / companies located in Java Island reached 350,665 or the equivalent of 56.56 percent of the total education businesses. These businesses include tutoring agencies, expertise course institutions, and other types of non-formal educational institutions. From this data, it does not include tutoring that has not been officially registered but already has a big name, for that the subject matter will be more in the 5 provinces with the most number of tutoring agencies.

\section{A. Impact of Pandemic on Tutoring Agencies in DKI Jakarta}

The income of the conventional tutoring agencies dropped after the Governor implemented the PSBB scheme on April 10, 2020. In the first month of this implementation, the income did not exist at all because there was no teaching and learning process at all. The Income continues to decline, even teaching places have to be temporarily closed to cut operational costs. In the midst of increasing needs, teachers are forced to be sent home. Some teaching teachers who are still students also experience problems due to increased operational costs for online lectures, while their livelihoods have stopped [4]. Covid-19 is not the main reason, but rather the successive economic impact caused them. The declining financial condition of the family amid the high costs of paying tutoring agencies. The existence of a national exam elimination policy were the main considerations of students for resigning.

Many students and their parents admit that they are still interested in joining a tutoring agencies provided that the facilities and services obtained are commensurate with the high cost that must be paid. They will rejoining to preparation for admission to public higher education institutions.

\section{B. Impact of Pandemic on Tutoring Agencies in East Java}

The home study policy in East Java province has been implemented starting March 16, 2020. Not only are teaching and learning activities at school closed, but course and training institutions or tutoring agencies in East Java have also officially closed. This results in no income for the tutoring agencies business in East Java and the business turnover of the tutoring agencies has dropped dramatically. The Cendikia tutoring agencies is one of the tutoring agencies in the city of Surabaya which has been severely affected by the Covid-19 pandemic. To attract students to join, this tutoring agencies strictly implements health protocols. Before the Covid-19 pandemic, the Cendikia tutoring agencies was able to guide as many as 20-30 students per day, but currently it is only able to guide 2 students in one week. In this Cendikia tutoring agencies there are 100 teaching staff and each of them is paid the rate of the student they supervise [5].

\section{Impact of Pandemic on Tutoring Agencies in Central Java}

The Several government policies that have succeeded in influencing of tutoring agencies include the requirement to conduct learning from home and the elimination of the National Examination. This requires that it must close their conventional service activities which have a long impact on decreasing the amount of business income. Rumah Akselerasi income has dropped to reach 80 percent, the special preparatory class for the national exam also ended in the middle of its implementation, this causes many students leave. The same thing happened to Smart Education Center and AIO Private tutoring agencies. The tutoring activities of both tutoring agencies have stopped completely following the implementation of this policy. This condition has led to new online teaching methods, many of which are given free of charge. This resulted in many teachers from conventional tutoring agencies being terminated or losing their income [6].

\section{Impact of Pandemic on Tutoring Agencies in West Java}

The high number of covid-19 cases has led to a policy of eliminating activities that cause crowds, one of which is the business activities of tutoring agencies. Ganesha Operation is one of a tutoring agency in Bandung that continues to survive the Covid-19 pandemic. This business is still surviving by following the trend of online tutoring methods using the Go Kreasi application and virtual conferences. There are indeed obstacles related to the departure of some students due to the economic conditions of their parents who are experiencing difficulties, but the numbers are small so that they can still be anticipated properly [7]

\section{E. Impact of Pandemic on Tutoring Agencies in North Sumatera}

Home learning policy has been implemented in North Sumatera since March 18, 2020. Schools and tutoring agencies are also closed and prohibited from providing face-to-face services. The number of students using tutoring agencies in North Sumatra Province has decreased which has resulted in a decrease in income from the tutoring agencies business. This is because most parents do not extend their child's learning period and the emergence of various kinds of free online tutoring. One of the tutoring agencies in North Sumatra, Smart Tutoring Agency which focuses on providing services in preparation for college entrance tests, has suffered a loss of IDR 30-50 million. About 30 teachers and their staff have been sent home following the implementation of the policy of eliminating national exams and postponing computer-based written exams for university entry [8]. 


\section{DISCUSSION}

\section{A. Product}

The kinds of tutoring agency products include the large variety of classes offered, the frequency of meetings, textbook facilities, and the compatibility of the tutoring material with the exam material. The thing that needs to be considered in products during a pandemic is the number of students in one class, to reduce the process of spreading the Covid-19 virus [9].

\section{B. Price}

The frequency of meetings, room facilities for learning, and learning modules are considered in determining the price, expensive or cheap to be relative depending on the suitability of the facilities offered. In this section, there is no change in facilities due to the pandemic, so that the decline in people's purchasing power can be a consideration. Even so, it is not advisable to reduce prices, because operational costs will increase.

\section{Place}

Easily accessible, the availability of transportation, and a good learning situation are the criteria of place to choosing a tutoring agency. There is no effect due to the pandemic, in the red and black zones face-to-face learning activities will be prohibited. So moving the learning location to another place is not a solution, because it will increase operational costs and change the location of the tutoring agency even further [10].

\section{People}

Teacher is an important figure who makes students and parents choose to study at the tutoring agency. Teaching time discipline, ability, teaching methods, and friendliness of all staff, are things that are of concern, so that there is no change due to the pandemic [11].

\section{E. Promotion}

The attractiveness of promotions and suitability of promotions with expectations are important factors to select a tutoring agency, it is including any discount or guarantee [12]. Promotional activities to schools cannot be implemented because all schools are closed. It can be overcome by using social media, because almost every student and parent has social media. So that promotional activities provide information when is the right time to start joining the tutoring agency.

\section{F. Physical Evidence}

The size of the room compared to the number of students, the existence of a generator, sufficient parking space, clean bathroom, lighting, Wi-Fi connection, and a canteen if there is a break time, are the facilities that students and parents pay attention to. The availability of hand washing at the entrance and hand sanitizer is of the greatest concern during a pandemic, and spraying of disinfectants during class changes is an added value.

\section{G. Process}

Registration procedures, easy-to-understand teaching and learning processes, and administrative services are factors that need attention. The teaching and learning process will be more conducive if the number of students is small and keep a distance, because students will be more focused on learning [13].

Parents are most influence the sustainability of the agency apart from being child funders, because parents can usually be the right promotional agents. For this reason, it is necessary to explain the variety of class products, promotions, and the learning process, as well as the latest physical evidence according to the current conditions that have followed the health protocol [14].

From SWOT analysis, market conditions and technology support, the convenience of the internet for learning online, the ease of time and space, and expenses for family education are all factors of opportunity to consider in choosing a tutoring agency during a pandemic [15]. The intense competition between agencies, expensive tuition prices, and high operating costs are the threat factors experienced by tutoring agencies at this time [16]. Improved management, well-known brands, and word of mouth to achieve wide recognition and reputation are the strength factors that need to be considered for the tuition agency to survive. Loyalty of teachers, unclear teaching abilities, and lack of training for teachers to develop are factors of weakness that occur during a pandemic [17]. For this analysis the conditions will be balanced, where students have difficulty in school lessons, needs increase, but income decreases.

The factors that can adjusted during a pandemic are the appropriate products, processes, and availability of physical evidence. It could be by providing online and offline class facilities, despite the tendency for parents and students to choose offline, but the choice of online classrooms shows that the tutoring agency continues to advance following technological developments. For the process which initially held face-to-face meetings, it also provides online exam practice facilities, so it makes learning easier. Besides that, it can limit the distance between students, providing means of washing hands and hand sanitizers is one physical evidence that is considered in choosing a tutoring agency. The tutoring agency should limit the number of students to half and spray disinfectants every change of class hours. For example, the Quantum Community is the choice of high-achieving students in school, because the number of students is limited, making it easier for students and teachers to interact. Even though online tutoring is currently popular, this interaction has a big influence on students in understanding the material presented compared to using online media [18]. When students and parents feel comfortable, they tend to remain loyal to the tutoring agency. 


\section{CONCLUSION}

Factors that need to be considered for the conventional tutoring agencies to survive are products and processes. Products by providing a variety of choices for offline classes, limiting the number of students. The process is by providing disinfectant spraying when the student leaves, and also the strict application of health protocols.

\section{REFERENCES}

[1] R.P. Astuti and E. Purwanto, "Perbedaan Self Efficacy siswa dalam menghadapi ujian nasional di SMP Negeri 1 Boyolali ditinjau dari keikutsertaan bimbingan belajar," Educational Psychology Journal, vol. 3, pp. 19-25, 2014.

[2] D. Purnamasari, Bisnis Industri Pendidikan yang Makin DiminatiTirto.ID, 2017. [Online] Retrieved from: https://tirto.id/bisnis-industripendidikan-yang-makin-diminati-cnRh [cited 2020 Oct 2].

[3] KPCPEN, Peta Sebaran, 2020. [Online] Retrieved from: https://covid19.go.id/peta-sebaran [cited 2020 Oct 2].

[4] Y.T. Andira, Dampak Covid-19 terhadap Tempat Bimbingan Belajar dan Guru Pengajarnya - Kompasiana.com, 2020. [Online] Retrieved from:

https://www.kompasiana.com/yunitatriandina/5e9bd9dcd541df2f0f32c4 e3/dampak-covid-19-terhadap-tempat-bimbingan-belajar-dan-gurupengajarnya [cited 2020 Oct 2].

[5] R.D. Santo, Lembaga Bimbingan Belajar Bisa Gulung Tikar KlikJatim.com, 2020. [Online] Retrieved from: https://klikjatim.com/lembaga-bimbingan-belajar-bisa-gulung-tikar/ [cited 2020 Oct 2].

[6] M. Sholekan, Pandemi Virus Corona Berimbas ke Bimbel, Ria: Pendapatan Turun Drastis - Tribun Jateng, 2020. [Online] Retrieved from: https://jateng.tribunnews.com/2020/05/05/pandemi-virus-coronaberimbas-ke-bimbel-ria-pendapatan-turun-drastis [cited 2020 Oct 2].

[7] R. Hironimus, Bimbel Ganesha Operation Tawarkan Program The Winning Team untuk Tembus Seleksi PTN - Halaman 3 - Warta Kota, 2020. [Online] Retrieved from: https://wartakota.tribunnews.com/2020/07/06/bimbel-ganesha- operation-tawarkan-program-the-winning-team-untuk-tembus-seleksiptn?page $=3$ [cited 2020 Oct 2].

[8] Y. Yetty, Pandemi Covid-19, Jumlah Siswa Bimbel Turun Drastis Harian Mistar, 2020. [Online] Retrieved from: https://www.mistar.id/edukasi/pandemi-covid-19-jumlah-siswa-bimbelturun-drastis/ [cited 2020 Oct 2].

[9] E. Monica, J.H. Matsum, and O. Okiana, Analisis Faktor Bauran Pemasaran Dalam Memberikan Kepuasaan Kepada Peserta Bimbingan Belajar Di Primagama, vol. 4, no. 9, pp. 1-14, 2015.

[10] Z.A.L.S. Arifin, U. Sumarwan, and M. Najib, "The Influence of Marketing Mix on Brand Image, Motivation and Students Decision to Choose Graduate Studies of IPB University,” J. Consum Sci., vol. 5, pp. 139-156, 2020.

[11] K.A. Leithwood, S.K. Louis, S. Anderson, and K. Wahlstrom, How leadership influences student learning: A review of research from the Learning for Leadership project. Wallace Found. New York: ERIC, 2004.

[12] R. Richardo, M. Hussin, M.H. Bin Norman, and H. Ali, "A student loyalty model: Promotion, products, and registration decision analysisCase study of griya english fun learning at the tutoring institute in wonosobo central Java,” Int J Innov Creat Chang., vol. 12, pp. 122-46, 2020.

[13] S. Suwatno, R. Rino, and R. Anggara, "High Schools Students' Decision in Choosing Tutoring Institution," In 1st International Conference on Innovation in Education (ICoIE 2018) (pp. 257-262). Atlantis Press, 2019.

[14] D.F.M. Phiri, and D.M.M. Ferguson, "Exploring Parents' Satisfaction and its Potential in Boosting Sales and Profits in the Tutoring Business Sector," J Small Bus Entrep Dev., vol. 4, pp. 1-9, 2016.

[15] S.L. Holloway, and H. Pimlott-Wilson, "Marketising private tuition: Representations of tutors' competence, entrepreneurial opportunities and service legitimation in home tutoring business manuals," Br Educ Res J. vol. 46, pp. 205-21, 2020.

[16] Z. Zulkifli and H. Wandebori, "Formulating Business Strategy: a Case of Tutoring Agency in Indonesia," J. Apl Manaj., vol. 16, pp. 271-84, 2018.

[17] T.A. Yu, "Case Study on the Development Strategy of TAL Education Group," J Innov Soc Sci Res., vol. 7, pp. 30-44, 2020.

[18] M. Saqr, J. Nouri, H. Vartiainen, and J. Malmberg, "What makes an online problem-based group successful? A learning analytics study using social network analysis,” BMC Med Educ., vol. 20, pp. 1-12, 2020. 